\title{
THE GENERAL TRANSPORT INFRASTRUCTURE - A KEY DETERMINANT OF COMPETITIVENESS OF TOURISM IN ROMANIA AND CEE-EU COUNTRIES
}

\author{
Mihai Costea, ${ }^{1}$ Cristian-Valentin Hapenciuc, ${ }^{2}$ Gabriela Arionesei ${ }^{3}$
}

\begin{abstract}
After the fall of communism, Romanian tourism was considered a sector which, by with relatively modest efforts, could be quickly restarted with the capacity to have a positive influence over the entire economic relaunch process. Although it has been more than 27 years, an economic revival through tourism has not yet occurred. Moreover, in recent decades, Romanian tourism has steadily lost some competitiveness in relation to other tourist destinations in the region. In this context, through this study, we tried to show that a major cause of the low level of competitiveness is represented by the significant deficiencies recorded in terms of the general transport infrastructure. The availability of a secure and fast transport network by road, air and water to the most important tourist centers of a country is vital. Without a general infrastructure no tourist resource, no matter how important, can be put forward in an efficient manner. Thus, we can unequivocally say that the absence or an insufficient development of infrastructure in Romania is the prime factor of the lack of development of tourism activity and of the serious deficiencies recorded when it comes to enhancement of the national tourism offer. This conclusion is supported by the analysis of the data provided by the World Economic Forum (through the Tourism Competitiveness Index) and EUROSTAT. To reflect Romania's position in the general picture of the competitiveness of the transport network, we performed a comparative analysis considering the results achieved by ten other EU countries in Central and Eastern Europe (hereinafter referred to as CEE-EU countries).
\end{abstract}

JEL Classification Numbers: L83, P52; DOI: http://dx.doi.org/10.12955/cbup.v5.906

Keywords: transport infrastructure, Romania, Bulgaria, tourism competitiveness, CEE-EU countries.

\section{Introduction}

According to Paicu and Hristache (2013) Romania can be proud of a variety of landscapes, a relatively rich cultural and historical heritage, and of the existence of some natural monuments and unique landmarks, some of them being UNESCO heritage sites. For this reason, in Romania many forms of tourism can develop: seaside, mountain, balneary tourism, hunting and fishing, itinerant tourism with cultural, religious valences, business tourism, rural tourism, ecotourism etc. However, the efficient development of tourism in Romania and the enlargement of its attractiveness towards foreign tourists and investors becomes literally impossible without an appropriate general infrastructure. We refer to the infrastructure of the air, land (road and railroad) transport, but also naval, especially because cruise ship tourism has been an ever growing segment in recent years. We proposed that through this study, we make an objective analysis of the transport infrastructure in Romania, in comparison with ten other member countries of the European Union, from Central and Eastern Europe (hereinafter referred to as CEE-EU countries). Throughout this study we emphasized the comparison with the neighboring country Bulgaria, because between these two countries the economic, geopolitical, historical and geographical similitudes are more evident. Including the tourism point of view, the potential is broadly similar, but, nevertheless, the degree of development of the tourism activity and the performances registered regarding the number of arrivals of foreign tourists, the number of nights spent or the average period of stay are clearly superior in the case of Bulgaria (Costea, Hapenciuc and Arionesei, 2016). Are there such differences also from the point of view of the general transport infrastructure, as determining factor of tourism competitiveness? This is the question for which we look for an answer in this study.

\section{Literature review}

The importance of transport infrastructure in the general picture of tourism competitiveness is confirmed by organizations like The World Economic Forum, and is the basis of the study of tourism competitiveness of 141 countries, including through the analysis of the pillars regarding the air, land and port transport infrastructure. Starting from the data obtained by the World Economic Forum through the Travel and Tourism Competitiveness Index, Kayar and Kozak (2010) make a comparison between 28 countries regarding tourism activity, concluding that air and land transport infrastructure are among the factors that influence tourism competitiveness the most of a destination. Another international organization that certifies the importance of transport infrastructure is the Organization

\footnotetext{
${ }^{1}$ Ștefan cel Mare University of Suceava, Romania, mihai_costeaa@yahoo.com

2 Ştefan cel Mare University of Suceava, Romania, valentinh@ @ seap.usv.ro

${ }^{3}$ Ştefan cel Mare University of Suceava, Romania, gabriela_arionesei@gmail.com
} 
for Economic Cooperation and Development (OECD). With a vast expertise, including the tourism field, OECD published in April 2013, through the tourism committee coordinated by Dupeyras and MacCallum (2013), a list of indicators useful for national governments in the analysis of the competitiveness of the tourism sector, air transport being among them.In the context of the study of competitive advantage, Crouch and Ritchie (1999) are part of the category of authors that consider infrastructure as being an indispensable element for the development of tourism activity. Before them, Kaul (1985) is one of the first authors that recognizes the importance of transport infrastructure in the growth of tourism competitiveness of a tourism destination, by creating new attractions. The more recent studies reconfirm the importance of transport infrastructure in obtaining a competitive position on the tourism market. For example, Khadaroo and Seetanah (2007) study the role of infrastructure in the increase of the number of tourists in the famous destination Mauritius. They find that transport infrastructure contributes positively to the attraction of tourists, especially those from Europe, USA and Asia. Vila, Darcy and Gonzalez (2015) study the impact of different factors on the accessible tourism competitiveness from Spain and Portugal. In their opinion, infrastructure becomes extremely important in gaining a bigger share of this market. Among authors that don't hesitate in their recent studies to discuss the importance of transport infrastructure in the growth of tourism competitiveness we mention: Cvelbar, Dwyer, Koman and Mihalič (2015), Khan, Qianli, SongBo, Zaman and Zhang (2017), Biemonte, Ferrini and Grilli (2016), Duval and Weaver (2016) and others.

\section{Methodology}

In order to analyse the disparities from the point of view of the transport infrastructure, we chose for comparison eleven countries: Romania, Estonia, Lithuania, Latvia, Slovakia, Slovenia, Hungary, Poland, the Czech Republic, Croatia and Bulgaria. Starting from the terminology proposed by the Organization for Economic Cooperation and Development - CEE, referring to the countries from the Central and Eastern Europe, we chose to refer in the study to the listed countries as CEE-EU countries, namely member countries of the European Union, situated in the Central and Eastern Europe. The comparative analysis was based first on the data obtained by the World Economic Forum through the Travel and Tourism Competitiveness Report, 2015. Practically, we chose to use the data regarding the Travel and Tourism Competitiveness Index (TTCI) and focus strictly on the pillars that assess air transport infrastructure and the land and port infrastructure. In order that the analysis is as complete as possible, we chose to process the data available from The National Institute of Statistics from Romania regarding the situation of public roads and EUROSTAT regarding the number of kilometers of highway or the length of railroads. In order to ensure comparability, the data obtained was processed with the help of Microsoft Excel, version 2007.

\section{Results and Discussion}

From the data obtained by the latest World Economic Forum Report from the year 2015, regarding the Travel and Tourism Competitiveness Index (TTCI), Romania is at the 66th position from 141 countries, while Bulgaria its direct competitor is in the 49th position. If we relate to pillars no. 10 (air transport infrastructure) and no. 11 (land and port infrastructure) of tourism competitiveness, we will see that Romania is by far the lowest placed country in the regional classification, especially from the point of view of land and port infrastructure (Table no. 1).

\begin{tabular}{|l|l|l|l|l|l|}
\hline \multicolumn{5}{|c|}{ Table 1: The 14 Pillars of Tourism Competitiveness at the CEE-EU Region Level } \\
\hline \multirow{4}{*}{} & Country & \multicolumn{3}{|c|}{ P10 } & \multicolumn{2}{c|}{ P11 } \\
\cline { 2 - 6 } & Pos. & Score & Pos. & Score \\
\cline { 2 - 6 } & Bulgaria & 79 & 2.5 & 79 & 3.3 \\
\cline { 2 - 6 } & Croatia & 53 & 3.1 & 44 & 4.2 \\
\cline { 2 - 6 } & The Czech Republic & 51 & 3.1 & 18 & 5.2 \\
\cline { 2 - 6 } & Hungary & 69 & 2.7 & 36 & 4.5 \\
\cline { 2 - 6 } & Poland & 73 & 2.6 & 47 & 4.1 \\
\cline { 2 - 6 } & Romania & $\mathbf{8 7}$ & $\mathbf{2 . 3}$ & $\mathbf{9 1}$ & $\mathbf{3 . 1}$ \\
\cline { 2 - 6 } & Slovakia & 129 & 1.8 & 43 & 4.2 \\
\cline { 2 - 5 } & Slovenia & 82 & 2.4 & 19 & 5.1 \\
\cline { 2 - 5 } & Estonia & 59 & 3.0 & 37 & 4.4 \\
\cline { 2 - 5 } & Lithuania & 86 & 2.4 & 33 & 4.5 \\
\cline { 2 - 5 } & Latvia & 52 & 3,1 & 42 & 4,2 \\
\hline Source: Author & \multicolumn{4}{|l}{} \\
\hline
\end{tabular}




\section{Air Transport Infrastructure}

Airborne connectivity is essential for carrying out air travels, that is why the role of this pillar is to measure the volume of air transport, the number of departures, the density of the airports, the number of airlines which operate in a country, the quality of the airport infrastructure for domestic and international flights. Considering this pillar, the lowest placed countries in the CEE-EU region are Slovakia (129th place with 1,8 points) and Romania (87th place with 2,3 points). In contrast, the most competitive countries in the region are Croatia, the Czech Republic and Latvia, all the three countries registering a score of 3,1 points. It's worth mentioning that all the CEE-EU countries have deficiencies regarding their air transport infrastructure, as none of them was placed in the first 50 positions at the global level, with the top lead by Singapore and the United Arab Emirates.

In contrast to Romania, Bulgaria is placed on the 79th position, with 2,5 points. The superiority in comparison with Romania is in the higher quality of the infrastructure. From this point of view, Romania is placed on the 104th position globally, worrisome if we consider that countries like Nicaragua, Guyana, Senegal, Ghana or Rwanda have a more modern and efficient air infrastructure.

Having a more modern infrastructure than Romania, Bulgaria managed to attract more airlines that operate line, low-cost and charter flights. Thus, according to the data obtained by IATA for 2014, in Romania there were 43 airlines of different dimensions, whereas in Bulgaria the number of airlines had reached 45 (Table no. 2). Although the number of airlines that operate flights from and to Romania is smaller than in Bulgaria, the air traffic is more intense from the point of view of the number of departures of the airplanes per mile of inhabitants. This result is normal, because the population of Romania is much bigger than the population of Bulgaria, that is why the need of air transport and implicitly, the number of domestic and international flights is higher.

Table 2: Comparative Analysis Romania - Bulgaria from the Point of View of Pillar 10 - Air Transport Infrastructure

\begin{tabular}{|c|c|c|c|c|}
\hline & \multicolumn{2}{|c|}{ Romania } & \multicolumn{2}{|c|}{ Bulgaria } \\
\hline & Place & Score & Place & Score \\
\hline The quality of the air transport infrastructure (score) & 104 & 3,6 & 69 & 4,3 \\
\hline Departures of airplanes per 1000 inhabitants & 80 & 2,3 & 87 & 1,6 \\
\hline The density of airports (per 1 million inhabitants) & 57 & 1,3 & 95 & 0,8 \\
\hline The number of airlines which operate in the analyzed country & 50 & 43 & 42 & 54 \\
\hline
\end{tabular}

Source: Author

Another aspect where Romania has a better position in comparison with Bulgaria is the density of airports per 1 million inhabitants: 1,3 in Romania, in comparison with 0,8 in Bulgaria. This greater number was predictable because as we mentioned, the population and the surface in square kilometers of Romania are clearly greater than that of Bulgaria. In absolute values, Romania has now 16 operational airports at Arad, Bacău, Baia Mare, Bucharest (2), Cluj, Constanța, Craiova, Iași, Oradea, Satu Mare, Sibiu, Suceava, Târgu Mureș, Timișoara and Tulcea, and Bulgaria has 5 airports at Sofia, Burgas, Varna, Plovdiv and Gorna Oryahovitsa.

\section{Land and Port Infrastructure}

In order that a destination can assume a competitive position, it must have an appropriate network of roads and railroads. Also, it is necessary to ensure optimum conditions of naval transport. Therefore, for the first stage the existence of ports where the cruise ships can anchor in safe and comfort conditions for tourists is necessary. One must not underestimate the importance of country roads, usually not asphalted, that can, to a certain degree, be a picturesque tourist attraction, evidently in specific contexts of time and space.

From the point of view of the land and naval transport infrastructure, the most competitive countries in the region are: the Czech Republic (the 18th place worldwide with 5,2 points) and Slovenia (19th place with 5,1 points). In contrast, Romania is on the last place at the CEE-UE region level (91st place with 3,1 points). One of the biggest problems that Romania faces is with its quality of roads, being placed on the 121 st place globally from this point of view. According to the World Economic Forum, Romania has, alongside the Republic of Moldova, the worst roads in Europe. Under these 
circumstances, Romania's claims for an increase in the domestic tourist flow in the coming years should be moderate, especially if we take into account that in the world classification of land and port infrastructure, Romania is placed lower than countries like Bangladesh (2,9 points), Cameroon (2,9 points), Sierra Leone (3 points), Zimbabwe (3,3 points), Malawi (3,3 points), Zambia (3,6 points) or Ethiopia ( 3,8 points).

\begin{tabular}{|l|l|l|l|l|l|}
\hline Table 3: Comparative Analysis Romania - Bulgaria Considering the Variables of Pillar 11- Land and Port \\
Infrastructure & \multicolumn{2}{|c|}{ Romania } & \multicolumn{3}{c|}{ Bulgaria } \\
\cline { 2 - 6 } & \multicolumn{1}{|c|}{ Place } & \multicolumn{1}{|c|}{ Score } & Place & Score \\
\hline & 121 & 2.8 & 106 & 3.1 \\
\hline The quality of roads (score) & 58 & 2.9 & 50 & 3.0 \\
\hline The quality of railroad infrastructure (score) & 104 & 3.4 & 68 & 4.2 \\
\hline The quality of port infrastructure (score) & 85 & 4.1 & 66 & 4.5 \\
\hline $\begin{array}{l}\text { The quality of domestic transport network (buses, trains, } \\
\text { taxis, etc) (score) }\end{array}$ & 21 & 4.5 & 22 & 3.7 \\
\hline The density of railroads per 100 square kilometers & 21 & & \\
\hline Source: Author
\end{tabular}

It is already more important for the economy of transport the existence of a modern road network. According to the National Institute of Statistics (2015), at the end of 2015, the public roads from Romania totalized $86.080 \mathrm{~km}$, of which $17.606 \mathrm{~km}(20,5 \%)$ of them were national roads, $35.316 \mathrm{~km}$ $(41,0 \%)$ county roads and $33.158 \mathrm{~km}(38,5 \%)$ local roads. From the point of view of this type of covering, Romania registered in the year $201532.641 \mathrm{~km}(37,9 \%)$ modernized roads (with heavy and medium-curing asphalt), $21.136 \mathrm{~km}(24,6 \%)$ roads with light blankets and $32.303 \mathrm{~km}(37,5 \%)$ paved and earth roads. It's worth mentioning that, from the total of national roads $35,2 \%(6.193 \mathrm{~km})$ are European roads, $4,2 \%(747 \mathrm{~km})$ highways, $1,6 \%(281 \mathrm{~km})$ three-lane roads, $10,3 \%(1.807 \mathrm{~km})$ fourlane roads. $0,1 \%(22 \mathrm{~km})$ six-lane roads.

Highways have a significant importance today because they are public roads which enable transport at higher speed and, at the same time, have the capacity to carry the increasing number of vehicles that run on public roads. By far the biggest network of highways is registered in Hungary and Poland (Table no. 4).

Table 4: Numbers of Kilometres of Highway in the CEE-EU Countries

\begin{tabular}{|c|c|c|c|c|c|c|c|c|c|c|}
\hline & 2005 & 2006 & 2007 & 2008 & 2009 & 2010 & 2011 & 2012 & 2013 & 2014 \\
\hline Bulgaria & 331 & 394 & 418 & 418 & 418 & 437 & 458 & 541 & 605 & 610 \\
\hline Czech R. & 564 & 633 & 657 & 691 & 729 & 734 & 745 & 751 & 776 & 776 \\
\hline Estonia & 99 & 99 & 96 & 104 & 100 & 115 & 115 & 124 & 140 & 141 \\
\hline Croatia & 1.016 & 1.081 & 1.156 & 1.199 & 1.244 & 1.244 & 1.254 & 1.254 & 1.289 & 1.290 \\
\hline Latvia & 0 & 0 & 0 & 0 & 0 & 0 & 0 & 0 & 0 & 0 \\
\hline Lithuania & 417 & 309 & 309 & 309 & 309 & 309 & 309 & 309 & 309 & 309 \\
\hline Hungary & 636 & 785 & 858 & 1.273 & 1.273 & 1.477 & 1.515 .5 & 1.515 .1 & 1.766 .9 & 1.781 .8 \\
\hline Poland & 552 & 663 & 663 & 765 & 849 & 857 & 1.070 & 1.365 & 1.482 & 1.556 \\
\hline Romania & 228 & 228 & 281 & 281 & 321 & 332 & 350 & 550 & 644 & 683 \\
\hline Slovenia & 569 & 579 & 579 & 696 & 747 & 768 & 768 & 769 & 770 & 770 \\
\hline Slovakia & 327.5 & 327.5 & 364.5 & 384 & 391 & 415.7 & 419.2 & 419.2 & 419.8 & 419.7 \\
\hline
\end{tabular}

Source: Author

Also, these countries are linked through highways to the neighboring countries. We find that in the case of Romania, the highway building is quite slow because within the period 2005- 2014 only 455 $\mathrm{km}$ were built, whereas in countries like Hungary or Poland, within the same period, more than 1000 $\mathrm{km}$ were built.

We must mention that the real necessities of highways are also directly proportional with the country's surface, respectively with the population and number of vehicles that run on public roads. Subsequently, relating the number of kilometers of highway to the country's population will show us that Romania registers the lowest results, in comparison with the other countries in the region (except Latvia that doesn't have any kilometer of highway) (Table no. 5) 


\begin{tabular}{||l|r|r|r||}
\hline Table 5: Number of Kilometres of Highway per Population of the CEE-EU Countries \\
\hline Country & $\begin{array}{c}\text { Km of highway in } \\
\text { the year 2014 }\end{array}$ & $\begin{array}{c}\text { Population according to } \\
\text { the IMF data }\end{array}$ & $\begin{array}{c}\text { Number of km of } \\
\text { highway per 100.000 } \\
\text { inhabitants }\end{array}$ \\
\hline Bulgaria & 610 & 7.200 .000 & 8.47 \\
\hline Czech Republic & 776 & 10.500 .000 & 7.39 \\
\hline Estonia & 141 & 1.300 .000 & 10.85 \\
\hline Croatia & 1.290 & 4.200 .000 & 30.71 \\
\hline Latvia & 0 & 2.000 .000 & 0.00 \\
\hline Lithuania & 309 & 2.900 .000 & 10.66 \\
\hline Hungary & 1.781 .8 & 9.900 .000 & 18.00 \\
\hline Poland & 1.556 & 38.000 .000 & 4.09 \\
\hline Romania & 683 & 19.900 .000 & 3.43 \\
\hline Slovenia & 770 & 2.100 .000 & 36.67 \\
\hline Slovakia & 419.7 & 5.400 .000 & 7.77 \\
\hline Source: Author & & & \\
\hline
\end{tabular}

Romania experiences deficiencies also regarding the port and railroad infrastructure, the results showing an inferiority in comparison with its neighbouring country Bulgaria. It is true that with the passage of time, railroads are less used. Table no. 6 presents the evolution of the railroads in the CEEEU region countries, within the period 2005-2014. One can see that in the majority of the countries the number of kilometres of railroad is diminishing every year, except Lithuania, where one can see significant increase, Hungary, that managed to increase in the year 2014 the railroad network by nearly $4000 \mathrm{~km}$ in comparison with the previous year. In Romania, the railroad network has a total length of over 20,000 km, being the 7th network largest in the European Union from this point of view.

\begin{tabular}{|c|c|c|c|c|c|c|c|c|c|c|}
\hline & 2005 & 2006 & 2007 & 2008 & 2009 & 2010 & 2011 & 2012 & 2013 & 2014 \\
\hline Bulgaria & 6.025 & 5.990 & 5.967 & 5.923 & 5.888 & 5.831 & 5.661 & 5.658 & 5.540 & 5.493 \\
\hline $\begin{array}{l}\text { Czech } \\
\text { Repub }\end{array}$ & 16.156 & 15.844 & 15.810 & 15.716 & 15.677 & 15.666 & 15.656 & 15.636 & 15.607 & N/A \\
\hline Estonia & 1.798 & 2.733 & 2.200 & 2.141 & 2.166 & 2.167 & 2.164 & 2.164 & 2.146 & 2.146 \\
\hline Croatia & 4.104 & 4.098 & 4.096 & 4.104 & 4.103 & 4.102 & 4.101 & 4.105 & 4.090 & 4.014 \\
\hline Latvia & 2.583 & 2.583 & 2.583 & 2.565 & 2.206 & 2.202 & 2.202 & 2.161 & 2.161 & 2.214 \\
\hline Lithuania & 2.187 & 2.187 & 2.180 & 2.179 & 2.182 & 2.184 & 2.184 & 2.188 & 2.188 & 2.188 \\
\hline Hungary & 12.735 & 9.513 & 9.223 & 9.208 & 9.208 & 9.178 & 9.445 & 9.421 & 9.523 & 13.253 \\
\hline Poland & 38.920 & 38.803 & 38.852 & 38.081 & 38.132 & 37.840 & 38.053 & 37.642 & 36.939 & 36.653 \\
\hline Romania & 21.228 & 20.677 & 20.668 & 20.648 & 20.520 & 20.482 & 20.129 & 20.077 & 20.284 & 20.241 \\
\hline Slovenia & 2.192 & 2.192 & 2.192 & 2.192 & 2.187 & 2.187 & 2.177 & 2.177 & 2.178 & 2.178 \\
\hline Slovakia & 3.658 & 3.658 & 3.629 & 3.623 & 3.623 & 3.622 & 3.624 & 3.631 & 3.631 & 3.627 \\
\hline
\end{tabular}

Source: Author

We think that the railroad transport will remain one of the main means of transport, especially for domestic travels. Also, all the transportation policies in the European Union present the advantages of railroad transport. These are also mentioned in the National Strategy for Sustainable Development of Romania - Horizons 2013-2020-2030.

The deficiencies of the passenger railroad transport in Romania are not related to the length of the network, but to its poor maintenance in the last decades, and the lack of modernization investments. These causes lead to the fact that the average speed of railroad transport is $50 \mathrm{~km} / \mathrm{h}$, lower than the registered speed within the interwar period $(60 \mathrm{~km} / \mathrm{h})$. Consequently, most of the times the travels are slow and tiresome. The low speed and the precarious comfort conditions lead to the decrease in the number of passengers beginning with the year 1990.

Regarding the average speed of railroad transport in Bulgaria, it is approximately $55 \mathrm{~km} / \mathrm{h}$, reduced in comparison with the developed countries from the European Union, where a speed of $150 \mathrm{~km} /$ hour is a decent speed. Recently, Bulgaria began a wide reform process in railroad transport. So that, this year, 
the Ministry of Transportation opened a new line of railroad transport which links the second biggest Bulgarian city-Plovdiv to the border with Greece and Turkey. On this line, the train reaches speeds up to $226 \mathrm{~km} / \mathrm{h}$, but the average speed is $170 \mathrm{~km} / \mathrm{h}$.

An indicator which shows a clear superiority of Romania in comparison with Bulgaria is related to the density of railroads per 100 square kilometers, but as we mentioned before, the quality of the railroad transport (through comfort and speed) must prevail, not necessarily the quantity.

Regarding the port infrastructure, we must mention that Romania has, in Constanța, one of the most important ports from the Black Sea, situated at approximately $340 \mathrm{~km}$ North from the Bosphorus Strait and $160 \mathrm{~km}$ South from the flow of the Danube into the Black Sea. At present the Constanta port also has a cruise ship terminal, but the greatest part of the activity carried out here is related to cargo ships, and less to the passenger transport. Although the cruise tourism represents one of the segments with the fastest growth in the industry, in the year 2016 there is no major cruise line with a tourism program that includes Constanța/ Romania. In the last years there were few attempts to include Romania in such a program, but most probably, because of the lower demand, the cruise lines chose to give up putting our country on the map with ports to be visited. After a period of increase of the number of passengers processed by the Constanța port within the period 2010-2014, in the year 2015, there was a registered decreases of approximately $46 \%$ in comparison with the previous year, as a consequence of the decrease of the number of the passenger ships which docked at the port (Table no.7).

Table 7: Number of Passengers and Passenger Ships Processed by Constanța Port

\begin{tabular}{|c|c|c|c|c|c|c|}
\hline & 2010 & 2011 & 2012 & 2013 & 2014 & 2015 \\
\hline Passengers & 21.286 & 23.878 & 34.010 & 54.226 & 64.861 & 35.000 \\
\hline Passenger ships & 58 & 43 & 52 & 69 & 95 & 36 \\
\hline
\end{tabular}

Source: Autor

By comparison, the commercial port of Bulgaria from Varna processed almost 21.000 passengers in the year 2014, while being, like the Constanța Port, concentrated especially on freight transport and less on passenger transport.

\section{Conclusions}

The results of the comparative analysis unequivocally show that Romania does not excel at any of the tourism competitiveness pillars that assess, from the qualitative and quantitative point of view, the general transport infrastructure. The investments in general transport infrastructure are the ones that could offer Romania an interesting route in the actual European context. Because there are obvious disparities regarding both infrastructure, and the relative contributions of tourism to the national economy of the countries in the region, Romania must be placed better in order to capitalize on the predicted tourism demand, that is why it is necessary that in the context of international competition, investments in tourism is intelligent and well directed. In order to achieve intelligent investments, a close collaboration is needed between the public and private sector from tourism and the related fields, and also making efforts to become attractive as country for foreign investors. We consider that only breaking the barriers in the development of tourism infrastructure and the general infrastructure may contribute to a strong gain of the competitive position of Romanian tourism on the international market.

The development and implementation of projects with European funding that take into account the improvement of priority problems that the Romanian tourism industry is faced with may constitute a viable solution for the revitalization of Romanian tourism. But, at present the level of these projects is very low, Romania being one of the countries which are faced with a low rate of absorption of funds with European funding. The slow economic evolution of ex-communist countries, like Romania, can be ascribed to the galloping evolution of corruption, a phenomenon that both Romania and Bulgaria were faced with in the last two decades and which affected the credibility of the two countries internationally, reducing also the attractiveness for direct foreign investments and the efficiency in attracting European funds.

Though measures for the improvement of the rate of absorption are necessary, we can affirm that, in the last years, progress was seen. For the tourism industry, the structural funds represent a major opportunity regarding the areas that have potential for development, and those underdeveloped. More 
than that, the European funding sources certainly help improve the competitiveness of tourism destinations on the traditional markets, but also on the emerging markets.

\section{References}

Annual Activity Report of the Port of Constanta (2015). Retrieved from

Bimonte, S., Ferrini, S., \& Grilli, G. (2016). Transport infrastructures, environment impacts and tourists' welfare: a choice experiment to elicit tourist preferences in Siena-Italy. Journal of Environmental Planning and Management, 59(5), 891-910.

Costea, M., Hapenciuc, C. V., Arionesei, G. (2016, September). Romania versus Bulgaria: A short analysis of the competitiveness of seaside tourism. In CBU International Conference Proceedings, 4, 471-482.

Crouch, G. I., \& Ritchie, J. B. (1999). Tourism, competitiveness, and societal prosperity. Journal of business research, 44(3), 137-152.

Cvelbar, L., Dwyer, L., Koman, M., \& Mihalič, T. (2016). Drivers of destination competitiveness in tourism: a global investigation. Journal of Travel Research, 55(8), 1041-1050.

Dupeyras, A., MacCallum, N. (OCDE) (2013) Indicators for Measuring Competitiveness in Tourism. A Guidance Document. OECD Tourism Papers, OECD Publishing. Retrieved from http://www.tourism-

generis.com/_res/file/4278/49/0/indicatorsforcompetitiveness.pdf

Duval, D. T., \& Weaver, A. (2016). Transport and infrastructure issues in Asian Tourism. The Routledge Handbook of Tourism in Asia.

EUROSTAT Database (2016). Eurostat.ec.europa.eu. Retrieved from

http://appsso.eurostat.ec.europa.eu/nui/show.do?dataset=rail_if_tracks\&lang=en

http://www.portofconstantza.com/apmc/portal/static.do?package_id=st_rap_anual\&x=get\&resource=RA_2015.pdf

International Monetary Fund, World Economic Outlook Database (April 2016). Imf.org. Retrieved from http://www.imf.org/external/pubs/ft/weo/2016/01/weodata/index.aspx

Kaul, R. (1985). Dynamics of Tourism: A Trilogy. Transportation and Marketing (Vol. 3). New Delhi: Sterling Publishers.

Kayar, Ç. H., \& Kozak, N. (2010). Measuring destination competitiveness: an application of the travel and tourism competitiveness index (2007). Journal of Hospitality Marketing \& Management, 19(3), 203-216.

Khadaroo, J., \& Seetanah, B. (2007). Transport infrastructure and tourism development. Annals of Tourism Research, 34(4), 1021-1032.

Khan, S. A. R., Qianli, D., SongBo, W., Zaman, K., \& Zhang, Y. (2017). Travel and tourism competitiveness index: The impact of air transportation, railways transportation, travel and transport services on international inbound and outbound tourism. Journal of Air Transport Management, 58, 125-134.

National Institute of Statistics, Romania (2015). Insse.ro. Retrieved from http://www.insse.ro/cms/sites/default/files/com_presa/com_pdf/lung_cailor_transp15r_1.pdf

Paicu, C. E., \& Hristache, D. E. (2013). Implicaţiile economice şi comunicaţionale ale turismului din România. Economie teoretică şi aplicată, 7(584), 105-115.

The Travel and Tourism Competitiveness Report (2015). Retrieved from http://www3.weforum.org/docs/TT15/WEF_Global_Travel\&Tourism_Report_2015.pdf

Vila, T. D., Darcy, S., \& González, E. A. (2015). Competing for the disability tourism market-a comparative exploration of the factors of accessible tourism competitiveness in Spain and Australia. Tourism Management, 47, 261-272. 